\title{
Die betekenis van die kerklike dogma
}

\author{
J H Koekemoer \\ Universiteit van Pretoria
}

\begin{abstract}
The meaning of the dogma

Because dogmatic decisions of the past are not guaranteed to remain relevant for contemporary temptations and attacks, and because the dogma is by intrinsically relative to the Word of God, this article argues that a critical interpretation of the dogma is essential. The purpose of such a critical interpretation must be to keep dogma relevant and alive. Therefore questions like the origin of the dogma, the essence of the dogma, the hermeneutics of the dogma and the task of dogmatics, should be answered.
\end{abstract}

\section{VRAAGSTELLING}

In 'n gesamentlike memorandum van die gespreksgenote in die tussenkerklike gesprek tussen die Nederduitsch Hervormde Kerk van Afrika, die Nederduitse Gereformeerde Kerk en die Gereformeerde Kerke in Suid-Afrika word in verband met die kerklike belydenisskrifte gestel dat daar aanvaar word dat die 'belydenisskrifte geheel en al ondergeskik is aan die onbetwisbare gesag van die Woord van God' (Handelinge van die Tussenkerklike Kommissie [TKK] 1989: Bylae C:604). Om hierdie rede is die belydenisskrifte dan ook altyd toetsbaar aan die Heilige Skrif.

Hiermee saam stel die memorandum

Ons wil nie die letter van die bewoording van die belydenis verabsoluteer nie. Ons aanvaar egter nie 'n breë en ongedefinieerde onderskrywing van die belydenis waarbinne enigeen basies vry is om self te bepaal wat vir hom die 'intensie' van die belydenis sou wees nie. Die besondere aard van belydenisskrifte eis dat hulle verstaan wil en moet word soos dit - binne die gegewe konteks - daar staan. Dit is so dat die ses en sestig boeke van die Bybel 'n verskeidenheid literêre genres verteenwoordig waarmee by die eksegese deeglik rekening ge- 
hou moet word om nie in biblisistiese, of fundamentalistiese vaarwaters te beland nie. Die belydenisskrifte het egter - ondanks eie primêre gerigthede: die Nederlandse Geloofsbelydenis teties; die Dordtse Leereëls antiteties-polemies; die Heidelbergse Kategismus meer kategeties - 'n eenduidige karakter daarin dat hulle feitelikseggend wil wees. Daarom eis die wese van belydenisskrifte om verstaan, bely en gehandhaaf te word soos dit binne hulle konteks daar staan.

(Handelinge van die TKK: Bylae C:604)

Nieteenstaande die mate van ooreenstemming word nogtans gestel: 'Die kwessie van die interpretasie van die belydenis en die implikasie aan die binding aan die belydenis het verskille wat op hierdie stadium ongedefinieerd is, na vore geroep' (Handelinge van die TKK: Bylae C:604).

Hierdie gemeenskaplike verklaring oor ooreenkomste en verskille in die gesprek maak 'n teologiese besinning oor die volgende vrae betekenisvol:

- Wat is kerklike dogma?

* Hoe het die kerklike dogma tot stand gekom?

* Wat is die plek van die kerklike dogma in die kerklike belydenis?

- Sou daar sprake kon wees van 'n hermeneutiek van die dogma en daarom ook van 'n hermeneutiek van die belydenisskrifte?

- Wat is die funksie van die dogmatiek in hierdie verband?

Alleen wanneer bogenoemde vrae bevredigend beantwoord is, kan 'n verdere sinvolle teologiese gesprek oor die verklaring van die Tussenkerklike Kommissie gevoer word.

'n Poging tot beantwoording van bogenoemde vrae word in die artikel aangebied.

\section{DIE ONTSTAAN VAN DIE KERKLIKE DOGMA}

Die opdrag aan die kerk is om die evangelie van Jesus Christus aan die wêreld te verkondig. In die uitvoering van hierdie opdrag bevind die kerk hom in die wêreld. In die woorde van Hendrikus Berkhof (1982:59) moet ons sê: Terwyl die kerk deel van die tyd is, is hy gerig op die ewigheid. Hy leef in die tyd en in die tyd staan hy voor die ewigheid. Verder word dit vir die kerk duidelik dat hierdie twee sake 
naamlik tyd en ewigheid, mekaar nie uitsluit nie. Dit is so omdat die kern van die evangelie wat die kerk moet verkondig, daaruit bestaan dat die Woord mens geword het. Anders gesê, beteken dit: Die Woord het die gestalte van ons geskiedenis aangeneem, Hy het self geskiedenis geword. Die Woord het 'n Joodse man geword wat opgetree het tydens die regering van keiser Tiberius. Die ewigheid het homself in jaartalle uitgedruk.

Natuurlik is juis hier van 'n paradoks sprake. Woord en mens is skynbaar onverenigbare teenstellings. Maar hier word die menslike diensbaar gemaak as woning van die Woord.

Vir die kerk het dit vroeg reeds nodig geword om hierdie paradoks te deurdink. Die kerk moes hom immers in die wêreld verantwoord oor hierdie evangelie wat hy verkondig. Met hierdie verantwoording wou hy sy geloof fundeer, nie bewys nie, omdat die Christelike geloof sy sekerheid in homself het en nouliks bewys hoef te word (Berkhof 1973:28). Die verkondiging van die evangelie het vroeg reeds by die kerk in 'n antwoord van 'n belydenisformule oor Jesus van Nasaret neerslag gevind. Die oudste konfessies wat uit hierdie prediking opgeroep is, het dan ook rondom die paradoks van geboorte, kruis en opstanding na vore getree. In hierdie verband kan gerus na 1 Korintiërs 15, Filippense 2 en 1 Korintiërs 11 gekyk word (Weber 1955: 39).

Omdat dit vir die kerk ook steeds daarom gegaan het om sy eie geloofsituasie denkend te verhelder (Berkhof 1973:28) was die behoefte aan nadenke oor hierdie antwoord op die Woord altyd kragtig. Dit mag nou vreemd klink dat daar gesê word dat die kerk 'n behoefte daaraan gehad het om 'n intellektuele verheldering van sy geloof te verskaf. In die grond van die saak spel geloof tog 'n relasie tussen God in Christus en die mens uit. En dit klink so sinneloos dat daar gepraat word van die intellektuele verheldering van 'n relasie. Die behoefte het hom egter self na vore gedring toe die relasie bedreig is en hy dring hom telkens weer na vore as die relasie opnuut bedreig word (Berkhof 1973:28).

Wie enigsins die moeite wil doen om in die kerkgeskiedenis te gaan delf sal die verskillende motiewe wat 'n rol gespeel het by geloofsrefleksie daar ontdek. Dit kan kortliks soos volg saamgevat word: Omdat van die vroegste belydenisse wat in 'n sendingsituasie ontstaan het, was dit eerstens ten dienste van die kategese gevorm. Vir die kerklike onderrig aan die lidmate van die kerk moes die kern van die geloofsrelasie onder woorde gebring word.

Dit het al gou geblyk dat daar ook in die wêreld 'n verkeerde verstaan van die paradoks van die evangelie plaasgevind het. Hierdie verkeerde verstaan het gemanifesteer in die ontstaan van dwaalleringe waarteen die kerk hom moes afgrens. 
Verder het daar geleidelik ook die behoefte aan 'n sistematiese samevatting van die geloofsinhoud by die kerk ontstaan. 'n Mens sou hierdie ontstaansproses van die kerklike konfessie wat die oorspronklike vorm van die dogma bevat, ook anders kon weergee. In so 'n weergawe moet net altyd in gedagte gehou word dat 'n konfessie nie dogma is nie, en alhoewel dit die oorspronklike vorm van die dogma bevat, moet dit altyd lewend wees. Die gemeente bely en leef immers sy belydenis.

Hierdie antwoord van die belydenis, want belydenis is altyd antwoord, nooit Woord nie, wil niks anders sê as dit wat in die apostoliese verkondiging ter sprake gekom het nie. En hierdie antwoord word altyd gegee in verantwoordelikheid teenoor die Woord wat hierdie antwoord oproep (Weber 1955:40).

Omdat die belydenis 'n openbare uitspraak is en 'n uitspraak is waarin in die openbaar bindinge aangegaan word (Wethmar 1977:100), tree verskillende motiewe in die ontstaan van belydenisuitsprake juis daarom na vore.

Interessant is nou om daarop te let dat alhoewel die dogma aanvanklik nog as belydenis uitgespreek is, onder andere in die Apostolicum en Nicaenum waarin die terme credo en credimus telkens voorkom, dit in die kerkgeskiedenis nie blywend die geval sou wees nie (Wethmar 1977:106).

Reeds uit die inleidingsterminologie wat in die Symbolum Chalcedonense gebruik word, tree 'n belangrike aksentverskuiwing aan die lig. Daar kom naamlik die terme homologein...ekdidaskomen voor. 'Ons leer dat bely moet word'. Weliswaar dra die inhoudelike Christologiese uitsprake van die Chalcedonense nog onmiskenbaar tekens van die doksologiese karakter wat, onder andere, steeds kenmerk is van 'n belydenis. Maar uit genoemde inleidingswoorde word tog duidelik dat dit nie meer om 'n liturgiese belydenis gaan nie, maar om die leer aangaande die regte belydenis (Wethmar 1977:106).

Hierdie leerelement in die belydenis sou hierna die ander elemente van ' $n$ belydenis al meer oorheers. 'n Verdere strukturele verskuiwing word in die 'Athanasium' sigbaar. Die inleidingswoorde van die simbool, wat die oor eienskappe van die Goddelike triniteit handel, stel:

Vir elkeen wat salig wil word, is dit voor alle dinge nodig dat hy die algemene geloof hou;

maar elkeen wat dit nie geheel en al ongeskonde bewaar nie, sal sonder twyfel verlore gaan. Die algemene geloof is dit....

Hier is nie alleen 'n verskuiwing van die daad van belydenis na die leer oor die regte belydenis merkbaar nie, maar die inleidings- en slotwoorde van die belydenis dui duidelik aan dat die moment van afgrensing wat implisiet in 'n belydenis is, nou 
eksplisiet geword het. Die uiterste konsekwensie hiervan is dat die negatiewe die positiewe oorwoeker en dat die dogmas hoofsaaklik uit negatiewe uitsprake geformuleer word. Met hierdie ontwikkeling tree dan nie alleen die doksologiese, maar ook die positiewe getuieniskarakter van 'n belydenis op die agtergrond (Schlink 1985:43).

Wethmar (1977:109) wys daarop dat met verloop van tyd die belydenis juridies verabsoluteer is. So het die belydenis dan 'n grootheid geword wat op grond van formele gesag aanvaar moet word en is dit nie meer 'n gegewene wat op grond van die getuieniskrag daarvan aanvaar moet word nie. So word die credere dan credendum. Dan beteken aanvaarding van die belydenis niks meer nie as ' $n$ intellektuele instemming met ' $\mathrm{n}$ aantal credenda en het die belydenis sy eksistensiële krag in die gemeente verloor. Op hierdie saak het die reformasie wel deeglik probeer om 'n korreksie aan te bring, maar die na-reformatoriese ortodoksie het spoedig hierin teruggeval.

By beide Luther en Calvyn het die dogma nie juridies nie, maar geestelik gefunksioneer. Daarom weier Calvyn dan ook in 1537 om die drie ekumeniese simbole as formele bewys van regsinnigheid te onderteken. Hy tree so op omdat hy steeds geweier het om die dogma as tiranieke wet te laat funksioneer. Hy wil dat die dogma steeds binne sy plek in die belydenis van die kerk gesien sal word. Dat hy die dogma aan die ander kant nie geringskat nie, is duidelik uit die opset van sy Institusie (Wethmar 1977:137). Vir die reformatore het die dogma sy gesag ontleen aan die feit dat dit die konkretisering is van die ontmoeting met God se Woord in die Heilige Skrif. Omdat die dogma die wyse is waarop die Woord van God in die geloof neerslag vind, beteken dit dat die dogma nie tot iets eiemagtigs teenoor die Woord van God kan verhard nie (Wethmar 1977:138).

\section{WAT IS KERKLIKE DOGMA?}

Na Weber (1955:43) óor die oorsprong en die probleme in verband met die begrip 'dogma' gehandel het, wys hy tereg daarop dat dogma 'n leerstellige beslissing en nie 'n leerstellige wet is nie. Die dogma moet steeds gerig bly op die prediking en op die kategese. Daarom is sy gesag dan ook nie ' $n$ vanselfsprekende gesag nie, maar is dit geleë in ' $n$ besluit wat weer en weer geneem moet word. Die noodsaak van die besluit is nie te beredeneer nie, omdat dit die enigste wyse is waarop die kerk van homself kan wegbeweeg en kan terugbeweeg na die Woord van God toe. Daarom is die vorm van die dogma vir die kerk, belydenis. Die dogma is relatief tot die Woord van God. Dit het gesag, nie as 'n onafhanklike woord nie, maar as 'n gehoorsame antwoord (Weber 1981:44-46). Juis omdat daar beperkings aan gehoorsaamheid is, 
kan die dogma verkeerd, onvolledig en fragmentaries wees. In dié sin word elke kerk dan ook voor 'n vraag gestel deur elke ander kerk wie se dogma van syne verskil (Weber 1955:53). Om hierdie rede is daar dan ook geen waarborg dat dogmatiese beslissings, wat in hulle tyd geldig was, hulle geldigheid in onveranderde formulerings sal kan behou teen nuwe aanslae en vrae waarmee die kerk te make het nie. Om hulle geldigheid te behou moet die konfessionele uitsprake in 'n nuwe konteks van 'n nuwe leerstellige beslissing ingeskuif word. Vir hierdie rede is kritiese interpretasie van die dogma van wesenlike belang (Weber 1955:53).

Omdat die dogma die wyse is waarop die Woord van God in die geloof neerslag vind, beteken dit dat die dogma nie tot iets eiemagtigs teenoor die Woord van God kan verhard nie. Die dogma het altyd 'n onafsluitbare openheid na vore. Dit kan nooit as die vanselfsprekende eiendom van die kerk beskou word nie, dit bly steeds voorlopig (Wethmar 1977:138).

Dit is relasioneel omdat dit uitdrukking is van 'n geloofsrelasie tussen mens en God, dit is relatief omdat dit voorlopig is, altyd die taal van sy tyd praat wat nie vanselfsprekend die taal van elke volgende geslag is nie. Daarom moet die paradoksale spreekwyse van die dogma altyd weer nuut gesê word. Dit moet steeds weer oorgedra word na die toekoms toe, maar in die proses moet dit ook eers vir die hede waar gemaak word.

\section{DIE HERMENEUTIEK VAN DIE DOGMA}

Die belydenis 'Jesus is Here' sê iets dogmaties. Hierdie belydenis is 'n paradoksale spreekwyse oor die Woord wat mens geword het. Hierin word ook enigsins duidelik hoe die belydenis die oorspronklike norm van die dogma is. Die kerk maak nie deur sy belydenis Jesus tot Here nie, maar op die wyse leef hy in die erkenning dat Jesus die Here is. So tree tegelyk ook die eskatologiese karakter van die belydenis na vore omdat die kerk doen wat elke tong behoort te doen.

In 'n sekere sin het die kerk ook steeds in sy belydenis sy vryheid en sy beskerming teen die wêreld beleef. Die sekularisasieproses het egter onder andere ook 'n diepgaande generasiekloof tussen die huidige geslag en vorige geslagte teweeggebring. Op dié wyse het daar vir baie 'n diepgaande vervreemding van die taal van die kerk, soos verwoord in sy dogma en konfessie, na vore getree. Om die dogma sy betekenis te laat behou en sodat die kerklike belydenis lewend kan bly, sal hierdie kloof van vervreemding oorbrug moet word. Hierin kry die Dogmatiek dan die taak om die dink- en taalvorm vir die oorbrugging te verskaf. So word die Dogmatiek dan diensbaar aan die hermeneutiese proses van tra-ditio, dit is die oordra van die geloof aan hulle wat dit in die tradisionele vorm nie verstaan nie (Berkhof 1973:29). 
Eintlik was hierdie behoefte om die geloof so oor te dra aan die huidige geslag altyd daar. Dit is waarskynlik ook die rede

- waarom Gregorius van Nissa sy Oratio Catechetica in 383 vir die kategese geskryf het;

- waarom Calvyn sy Institusie in 1536 ook kategeties gerig het;

* waarom Irenaeus in 185 sy Adversus haereses teen dwaalleeraars gerig het;

* waarom Karl Barth sy Dogmatiek ten dienste van die prediking geskryf het, en

* waarom Noordmans sy Dogmatiek as spreekreël van die kerk gesien het.

Ander het weer die geloof geformuleer in bewuste konfrontasie met die denkklimaat van die tyd. Alhoewel Schleiermacher as die eerste groot eksponent hiervan gesien word het, Origenes in 220 in 'n sekere sin al hierdie motief gebruik (Berkhof 1973:29).

In hierdie verband waarsku Berkhof (1973:31) dat wanneer 'n dogmatikus hiermee besig is, hy nie meer in sy eie gedagtes oor God as in God self geinteresseerd moet wees nie. Daar moet in gedagte gehou word dat teologisering ook te make het met die ontmoeting tussen God en die teologiserende mens, met 'n relasie dus. Daarom kan Dogmatiek ook gesien word as 'n sistematiese deurdenking van die inhoud van die relasie wat God in Christus met ons daargestel het.

Die sentrale hermeneutiese probleem van die dogmatikus is dat hy 'n gesaghebbende tekstradisie in 'n nuwe historiese omgewing in moet vertaal waarop die dogmatiese teks nie direk betrekking gehad het nie. Om dit te kan doen sal die volle historisiteit van die dogmatiese uitsprake herken moet word, asook die noodsaak om die betekenis van die dogmatiese teks van een historiese situasie na 'n ander oor te dra, en dan so oor te dra dat die gesaghebbendheid daarvan vir die Christelike geloof bewaar kan bly (Ommen 1975:87). Op dié wyse sal daar 'n beweging tussen die historiese dogmatiese uitspraak en die huidige situasie van die geloof moet wees. Daarom het Ebeling dan ook in dié verband opgemerk dat die Dogmatiek nie alleen tot uitdrukking moet bring wat betekenisvol was nie, maar wat betekenisvol is (Ebeling 1963:320). So is Dogmatiek nie net in die traditio geïnteresseerd nie, maar ook in die actus tradendi.

Wanneer daar met hierdie actus tradendi besig is moet nie alleen gekyk word na die dogmatiese stelling nie, maar moet dit ook gelees word teen die agtergrond van 'n bepaalde geloofstradisie wat dikwels 'n direkte invloed op die formulering daarvan uitgeoefen het. 'n Goeie voorbeeld hiervan is die verandering van 'God uit God' na 'waaragtige God uit waaragtige God' wat deur die konsilie van Caesarea aan die geloofsbelydenis van Nicea aangebring is (Ommen 1975:176). Om dit te 
verstaan sal dit teen die agtergrond van daardie geloofstradisie gelees moet word.

Hierdie kan ook dien as voorbeeld hoe 'n geloofsbelydenis in 'n nuwe tyd nuut gesê kan word, of soms net anders gesê kan word, om nuwe situasies die hoof te bied. Miskien is 'n nog beter voorbeeld die triniteitsdogma uit die vierde eeu. In wese sê dit niks meer as 'Jesus Christus is Here', nie. Dit verstewig selfs nie eers hierdie ou belydenis nie. Dit sê hierdie ou belydenis alleen nuut binne 'n nuwe taalraamwerk wat gemik was teen 'n bepaalde kettery en die bedreiging van die kerk na buite. Die enigste motief hieragter is om die voortgaande proses van 'n regte belydenis na vore te bring. Die antwoord van die gemeente op die Woord in die vorm van 'n belydenis, moet in elke tyd lewend gehou word. Hier is geen sprake van 'n nuwe ontdekking nie. 'n Ou belydenis word alleen in nuwe omstandighede nuut gesê. En dit word gedoen omdat die $O u$ Woord deur nuwe dwalinge aangeval word. Die kerk word geroep om onder nuwe omstandighede, in die lyn van sy tradisie, die paradoks dat die Woord mens geword het, opnuut te deurdink en te bely. Hierdie proses bring mee dat 'n nuwe belydenis 'n oue nooit tot niet maak nie, maar dit alleen maar insluit. Daarom het die konfessies van die reformasie ook die simbole van die ou kerk erken. So bewaar die kerk nie alleen sy tradisie nie, maar keer hy ook dat dit nie versteen nie (Weber 1955:30-31).

Om hierdie rede het Luther en Calvyn ook nie 'n dogmalose Christendom voorgestaan nie, maar die doctrina Christiana, tot die mate waarin dit die lewende krag van die evangelie bewaar het, as gesaghebbend aanvaar (Ommen 1975:19). Dit is die Gereformeerde ortodoksie wat die dogma opnuut weer laat versteen het omdat dit die leeruitsprake van die kerk losgemaak het van hulle historiese konteks en as ewige waarhede geproklameer het wat nie aan kritiese interpretasie blootgestel hoef te word nie. Dan lê hulle krag daarin dat hulle alleen maar herhaal hoef te word en nie nuut of selfs anders gesê hoef te word nie.

In hierdie verskuiwing in die reformatoriese teologie is die openbaring nie meer gesien as die lewende Woord van God nie, maar as die meedeel van teologiese leerstellings.

Die doctrina is geformuleer in terme van die Arestotelies-skolastiese wetenskapsideaal en is nie meer in die eerste plek gesien as 'n saak van die prediking nie, maar as die konstatering van synswaarhede. Die kenniselement van die geloof is losgemaak uit die konkrete heilsituasie 'Coram Deo' waarin dit tot stand gekom het. In die verhouding tussen leeruitsprake en Skrif wat so tot stand kom is dat in die Skrif gesoek word na 'dicta probantia' om die leeruitsprake te begrond. Wat vir die reformasie 'n onverbreeklike eenheid was in die 
religieuse heilsituasie 'Coram Deo', het uiteengeval in 'n dualisme van leer en lewe, van objektiewe kennis en persoonlike toe-eiening.

(Wethmar 1977:139)

Hier is een kardinale saak van 'n belydenis vergeet, naamlik dat 'n belydenis binne ' $n$ bepaalde verstaanshorison in die geskiedenis plaasvind. Dan sal dit noodwendig so wees dat as die verstaanshorison verander, die belydenis dan herinterpreteer moet word in terme van die verstaansvooronderstellings van 'n nuwe verstaanshorison. As dit nie so gebeur nie, verloor die belydenis sy lewenskrag en verstar en versteen dit. Vir die dogmatikus het hierdie proses van terugvra in 'n nuwe verstaanshorison sy laaste kriterium in die Heilige Skrif. Die Heilige Skrif is die normatiewe getuienis van die Christelike geloof waaragter daar nie teruggevra kan word nie.

Hoe noodsaaklik hierdie proses van sinvolle terugvra en vertolking binne nuwe verstaanshorisonne vir die Dogmatiek is, blyk veral uit die feit dat die dogmatikus nie meer gesien word as die gesaghebbende ideoloog van sy kerk wat net die tradisionele moet verwoord nie. Hy word vandag veeleer gesien as 'n spoorsnyer, 'n ontdekkingsreisiger wat in die proses van verstaan en verstaanbaar maak van die konfessie ook deel moet hê aan die proses om dit lewend te laat word.

Natuurlik kan die Dogmatiek nooit sonder die konfessionele dimensie funksioneer nie, omdat die verworteling in ' $n$ lewende kerk met sy tradisie vir die Dogmatiek van wesenlike belang is. As 'n dogmatikus homself bo sy konfessie stel, stel hy hom buite die kerk waaruit en waaroor hy wil reflekteer. Hy moet dankbaar die dieptepeilinge en die daarby behorende beslissings van sy kerk of konfessie deurdink en tot uitdrukking bring. Hy sal egter in gedagte hou dat dit geen absolute gesag het nie, dit het alleen betreklike gesag, omdat dit niks anders is nie as die belydende antwoord van die gemeente op die Woord van God. Die Skrif staan bo hierdie dinge en in hierdie deurdenkings-, verstaan- en oordragproses moet die Skrif die konfessionele tradisie komplementeer, kritiseer en relativeer (Berkhof 1982:22).

In hierdie verband sal net in gedagte gehou moet word dat die Skrifberoep in die Dogmatiek in die jongste tyd diepgaande van karakter verander het. Daar word baie minder met los tekste gewerk. Die Bybelse getuienisse word nie soseer gebruik om 'n sisteem daar te stel nie, maar wel as die fondament van 'n bepaalde pad. Hierdie pad verander dikwels van rigting en bied ook wisselende perspektiewe. Hoe in gehoorsaamheid aan die getuienis van die Skrif op hierdie aangeduide pad voortgegaan moet word, is nie so maklik uit te maak nie. Die pad moet telkens in sy totaliteit bekyk word om dan so die situasie in die hede daarmee in relasie te bring. 
So word daar saam met ' $n$ lewende gemeente, in 'n bepaalde historiese situasie met 'n bepaalde tradisie, gepoog om opnuut weer op die pad belydend op die Woord van die lewende God te antwoord.

Omdat die Dogmatiek tot uitdrukking moet bring dit wat betekenisvol is en nie net dit wat betekenisvol was nie, beteken dit dat die dogmatikus die voortgaande taak het om die 'tradisie' van die Christelike geloof te 'vertaal' in die veranderde situasie van die geloof van sy eie tyd. Om te sê wat die vadere in 'n bepaalde teks bely het, sê nie outomaties wat die betekenis daarvan vir die moderne milieu moet wees nie. Daarom is die hermeneutiese proses van verstaan so belangrik en noodsaaklik. Hierdie proses, wat Gadamer (1965) beskryf het as die effektiewe versmelting van horisonne, veroorsaak dat in 'n nuwe situasie 'n ou konfessie ook kan inspreek. Dit kan natuurlik alleen geskied as die situasie van die interpreteerder ook in die proses verreken is. Daar is nie so iets as 'n vooronderstellinglose benadering nie. In die seleksie van historiese gegewens, die analise van data en die inbeweeg in 'n ander era in, speel die situasie van die interpreteerder al 'n rol. Die situasie van die interpreteerder is egter nêrens in die proses so sterk betrokke as daar waar die vraag van die betekenis van die verlede vir die hede na vore tree nie (Ommen 1975:181).

In 'n baie groot mate word die vooronderstellings van die interpreteerder deur sy tradisie gevorm, en vorm so ook weer die kontakpunt tussen hom en die teks uit die verlede. Sy dogmatiese vooronderstellings is in hom ingegrafeer deur die gemeente waarvan hy deel is. Dit wil nie sê dat sulke vooronderstellings sonder korreksie funksioneer nie. Die erkenning daarvan en die openheid van die teks maak korreksie juis moontlik. In sy interpreterende arbeid is die dogmatikus nooit 'n geïsoleerde en outonome figuur nie, maar 'n deelgenoot aan 'n voortgaande tradisieproses wat met' 'n konkrete historiese gemeente saamgaan (Ommen 1975:85) - 'n gemeente wat altyd weer belydend op die Woord van God moet antwoord.

\section{SLOTWOORD}

Egte teologisering, ook in bogenoemde verband, en dit moet steeds ingeskerp word, het maar ten dele met die intellektuele vermoëns van die beoefenaar te doen. Dit het eweneens te doen met die ontmoeting tussen God en die teologiserende mens, met ' $n$ regte relasie dus. Dit beteken egter nie dat daar nie denkend in die teologie te werk gegaan kan word nie. Geloof het seer sekerlik met'n relasie te make, maar dit sluit denke nie uit nie. Alhoewel die twee sake nie met mekaar vereenselwig mag word nie, sluit dit mekaar nie uit nie. Dit beteken egter wel dat alle egte denke oor God voortkom uit 'n ontmoeting met God en gerig is op 'n ontmoeting met God 
(Berkhof 1973:32). Die gemeente van vandag moet steeds in sy belydenis antwoord op hierdie Godsontmoeting, en hierin kan die antwoord van sy voorgeslagte vir hom mede die pad aandui.

Dit maak 'n teologiese gesprek tussen die gespreksgenote van die Tussenkerklike Kommissie oor die sake wat in die artikel aangedui is, noodsaaklik. So 'n gesprek sal nie alleen lei tot 'n beter verstaan van die belydenisskrifte nie, maar ook daartoe bydra dat die 'ongedefinieerde' verskille ten opsigte van die interpretasie van die belydenisskrifte wel gedefinieer kan word.

\section{Literatuurverwysings}

Berkhof, H 1973. Christelijk geloof. Nijkerk: Callenbach.

Berkhof, H 1982. Inleiding tot de studie van de Dogmatiek. Kampen: Kok.

Ebeling, G 1963. Word and Faith. Philadelphia: Fortress.

Gadamer, H G 1965. Warheit und Methode: Gründzüge einer philosophischen Hermeneutik. Tübingen: Mohr.

Ommen, B 1975. The hermeneutic of dogma. Montana: Scholars Press.

Schlink, E 1985. Ökumenische Dogmatik. Göttingen: Van den Hoeck.

Tussenkerklike Kommissie van die drie Afrikaanse Susterkerke, 1989. Die Woord van God: Ooreenstemming en verskille in die Skrifbeskouing van die Gereformeerde Kerke in Suid-Afrika, die Nederduitse Gereformeerde Kerk en die Nederduitsch Hervormde Kerk van Afrika. Ongepubliseerde Handelinge van die TKK, Deel III, 1982-1989. Pretoria: Kital.

Weber, O 1955. Grundlagen der Dogmatik. Neukirchen-Moers.

Wethmar, C J 1977. Dogma en verstaanshorison. Amsterdam: Rodopi. 